\title{
Divine Doctors: The Construction of the Image of Three Greek Physicians in Islamic Biographical Dictionaries of Physicians ${ }^{1}$
}

\author{
Doctores divinos: construcción de la imagen \\ de tres médicos greco-romanos en los diccionarios \\ biográficos islámicos de médicos
}

\author{
Keren Abbou Hershkovits \\ McGill University, Montreal, Canada \\ Zohar Hadromi-Allouche \\ University of Aberdeen, United Kingdom
}

Este artículo analiza la manera en que los autores de tres diccionarios biográficos islámicos medievales retrataron la vida y características de las tres figuras más destacadas de la medicina greco-romana: Asclepio, Hipócrates y Galeno. Se presta especial atención al vocabulario y al estilo empleado en las biografías, así como a su relación con otros géneros literarios o figuras. El análisis de estas biografías revela un considerable parecido entre el retrato de estos tres médicos greco-romanos y la vida de algunos profetas en el Islam, especialmente la del Profeta Muhammad. Asimismo, estas
This paper examines the way authors of three medieval Islamic biographical dictionaries portrayed the lives, behavior and characteristics of three key figures of Greco-Roman medicine, Asclepius, Hippocrates and Galen. Particular attention was given to the vocabulary and phrasing used in the biographies, and associations with other literary genres or figures. An analysis of these biographies demonstrates a significant resemblance between the portrayal of these Greco-Roman physicians and the lives of prophetic figures in Islam, and especially that of the Prophet Muhammad. In

1 Acknowledgments: the authors wish to thank Daniella Talmon Heller and Gerald Hawting for reading a previous draft of this paper and making helpful comments. A shorter version was presented at the "Literature and History: Middle Eastern Perspectives" workshop held at the Ben-Gurion University of the Negev between 31 May and 3 June 2010. We would like to express our gratitude to the organisers, Ariel Moriah Sheetrit and Yair Huri, as well as to the panelists Ahmad al-Rahim, Nimrod Hurvitz and Daniella Talmon Heller, and to the workshop participants, who all contributed valuable comments. We would also like to thank Faith Wallis, for giving much valuable advice and many suggestions, and Cristina Álvarez Millán, who generously agreed to translate the abstract into Spanish. Keren Abbou Hershkovits wishes to thank the Transmission Translation and Transformation research group at McGill University for their generous Scholarship. Special thanks are also due to our anonymous readers, for their valuable insights. All mistakes remain our own. 
biografías presentan elementos atribuidos a musulmanes piadosos.

Este estudio demuestra que los biógrafos musulmanes construyeron esas biografías como parte de una tendencia general a asociar la medicina con el Islam y los orígenes del saber médico con la sabiduría profética. Igualmente, sostiene que las connotaciones y el uso de esa terminología particular permite una visión positiva de la ciencia de la medicina en las obras islámicas que les dieron cabida.

Palabras clave: Islam; medicina; literatura biográfica; profecía; médicos greco-romanos; Asclepio; Hipócrates; Galeno. addition, these biographies align with features attributed to pious Muslims. This study demonstrates that Muslim biographers constructed these biographies as part of a general tendency to associate medicine with Islam, and the origins of medical knowledge with prophetic wisdom. This study mantains that the connotations and use of this particular terminology allows for a positive view of the science of medicine in these Islamic compositions in which they were included.

Key words: Islam; Medicine; Biographical literature; Prophecy; Greco-Roman medicine; Asclepious; Hippocrates; Galen.

\section{Introduction}

References to Classical Greek individuals appear in various genres of Arabic literature, including scientific texts (that is, those dealing with philosophy, mathematics, astronomy, logic and medicine) and adab literature. In some sources, these figures are depicted positively, while in others they appear as neutral or even negative. ${ }^{2}$ This paper focuses on the way that three Greek physicians were portrayed in biographical dictionaries of the $10^{\text {th }}-13^{\text {th }}$ centuries, and argues that the Muslim biographers constructed these biographies with the intention of establishing a close relationship between medicine and prophethood. ${ }^{3}$

The Arabic biographical dictionaries present several questions for the modern reader: Who was their intended audience? What was the framework within which they were written? What was the social status of the sciences among the intellectual elite? In a seminal article, Fedwa Malti-Douglas argues that the authors of the Arabic biographical dictionaries chose from a range of available material which details to include and which to omit, and that the arrangement of the material chosen was given careful consideration. Emphasis was given to particular aspects, attributes and characteristics of the subject, with the result that

2 See, for example, the harsh critique expressed by al-Ghazālī in al-Munqidh min alDalāl against philosophers, whom he regards as heretical and dangerous.

${ }^{3}$ On biographical dictionaries, their character, and the information derived from this genre see Hamilton, "Islamic Biographical Literature", pp. 54-58; Rosenthal, A History of Muslim Historiography; Young, "Arabic Biographical Writing”; al-Qādīi, "Biographical Dictionaries: Inner Structure"; al-Qādīi, "Biographical dictionaries as the scholars' alternative"; Bray, "Literary Approaches". 
the structure of the biographies reveals more about the intentions and views of the authors than of the subjects. ${ }^{4}$ Drawing on this observation, it is here argued that the information that Muslim biographers chose to include in their biographies of Greek physicians, as well the arrangement of this information and the language in which it was transmitted, reveal the ways in which the authors perceived medicine, knowledge and the role and origins of medical knowledge. This provides new insights into the perception of medicine in Islam, and thus contributes to the ongoing process of scholarly re-examination of the Islamic attitude towards the sciences during the Ayyubid and early Mamluk periods.

Until recently, the mainstream scholarly position was that some time after the $12^{\text {th }}$ century, and no later than $15^{\text {th }}$ century, scientific creativity ceased in Islam. Muslim scholars instead merely repeated the sayings of their predecessors, summarising or explaining them ('așr al-Inhitạt ), while scientists faced persecution or opposition from figures such as Ibn Taymiya (d. 1328), who was very rigidly opposed to anything that was not strictly Islamic. This impression was gained from studies of the period based on religious or political texts; a reading of scientific texts, by contrast, shows that this interpretation is inaccurate, although the social status of science remains unclear. François Charette's recent book on astronomical instrumentation calls for a complete revision of how scientific activity in the post-classical period of Islam should be interpreted; he notes that many manuscripts still need to be edited and studied, and he criticises modern scholars for making generalising statements regarding the teaching of the sciences in madaris while ignoring the vast textual output of the period. Furthermore, he argues that modern scholars disregard astronomical content included in theological texts. In other words, modern scholars search in the wrong place for creative astronomical study. ${ }^{5}$ In fact, astronomy flourished during the Mamluk period, ${ }^{6}$ and in astrological form generated much attention (and critique).

Another problem in assessing attitudes towards the sciences is that there was no clear curriculum. Scholars taught in madāris and

${ }^{4}$ Malti Douglas, "Controversy and Its Effects".

${ }^{5}$ Charette, Mathematical Instrumentation, XIX-XX.

${ }^{6}$ On the need of further study of scientific texts in order to gain a more reliable picture of the attitude towards astronomy in the Mamluk period, see: Kennedy, "Astronomy under the Mamluks". See also: Charette, Mathematical Instrumentation, p. 9. 
mosques, but not just at these locations. In fact, most teaching took place on a private basis, with students coming to a particular teacher, usually to learn about a specific subject or treatise. Such a complex system of teaching and learning makes it hard to know what exactly was taught, or when and where. ${ }^{7}$

The attitude of rulers toward science is also complex. For instance, Michael Chamberlain's study of the relationships between various notables of Damascus between the $12^{\text {th }}$ and $14^{\text {th }}$ centuries includes several examples of teachers who maintained teaching positions in various sciences, including philosophy, natural sciences and medicine. The fact that there was no defined curriculum allowed for great flexibility, and scholars could choose their subject and materials as they pleased. ${ }^{8}$ Chamberlain interprets the dismissal of teachers and criticisms of particular curricula in this social context as a part of a struggle among intellectual élites looking to preserve or increase their power, rather than as representative of disapproval of science. A similar ambiguity regarding the status of science can be seen in $10^{\text {th }}$-century al-Andalus, ${ }^{9}$ while Oya Pancaroğlu argues, based on a study of Kitāb al-Diryāq (Book of Antidote) and its illustrations, that in $14^{\text {th }}$-century Anatolia scholars and intellectual activity were part of the court. ${ }^{10}$

This picture of science is further complicated by the unique and ambiguous status of medicine in the three monotheistic religions. Although the theoretical basis of medicine was often considered to be Greek and Syriac, it was never situated on the same plain as other branches of science; it received only little critique, or none. ${ }^{11}$

${ }^{7}$ For a general discussion regarding teaching as a private association see: Berkey, "Tradition, Innovation and the Social Construction", pp. 53-54. See also: Petry, "Scholastic Stasis in Medieval Islam"; another study illuminating the issue of the study of science during the early Mamluk period is Sonja Brentjes' "Reflections on the Role of the Exact Sciences". Brentjes demonstrates the high esteem in which various scholars practicing medicine and exact sciences were held. Furthermore, she discusses the various localities of the study of the exact sciences, including Madarris. According to Brentjes, the modern conception of criticism of the cultivation of science disregards textual evidence that demonstrates that in most cases such criticism was the result of personal rivalry or social conflicts, rather than actual rejection of the sciences.

${ }^{8}$ Chamberlain, Knowledge and Social Practice, pp. 84-86, 171-175.

${ }^{9}$ For a discussion of the attitude towards science in al-Andalus see: Monès, "The Role of Men of Religion", see also the introduction to this book, especially xix ff.

${ }^{10}$ Pancaroğlu, "Socializing Medicine".

${ }^{11}$ For a general overview of Islamic medicine and medical approaches see: Pormann and Savage-Smith, Medieval Islamic Medicine. 


\section{Background}

\subsection{Choice of sources}

The kind and form of information contained in Arabic biographical dictionaries make them the main source for attitudes towards science during the period during which they were written, since they contain details relating both to individual Greek medical careers and to the development of medicine in general. Other sources consulted include medical treatises, wisdom literature and works in other genres in which Greek physicians are mentioned. These sources tend to focus on the medical authority and knowledge of particular physicians, quoting sayings that are attributed to them, ${ }^{12}$ although some accounts of personal characteristics can also be found. Such is the case with, for example, al-Bīrūnī's Risāla fi fihrist kutub Muhammad b. Zakarīyā al-Rāzin, despite its focus on chronology. Similarly, Ibn al-Nadīm's Fihrist is a bio-bibliographical text, dedicated both to books and their authors. Both works use, or criticise, Ishāq b. Hunayn's treatise Ta'rīkh al-Atibb $\bar{a}$ ', which focuses on chronology and contributions to medical knowledge, rather than on the traits of individual doctors. This treatise serves as the starting point for this study. ${ }^{13}$ Another important source is al-Sijistānì's Șiwān al-Hikma, which belongs to the wisdom literature genre. Some of the anecdotes recorded in it can be used for illuminating the physicians' characters. ${ }^{14}$ On the other hand, Tabaqa al al-Umam by Sâa id al-Andalusī (d. 1070) discusses the various sciences and the transmission of science throughout generations and between nations. Medicine, however, he only mentions briefly, as he is more interested in philosophy and astronomy (being an astronomer himself). In the short paragraph devoted to medicine, al-Andalusī mentions Hippocrates and Galen as important physicians, and when they lived. ${ }^{15}$

Several biographical dictionaries dedicated to practitioners of science appeared between the $10^{\text {th }}$ and the $13^{\text {th }}$ centuries, in various geographic regions. The five most significant are Ibn Juljul's (944-after

${ }^{12}$ For an elaborated discussion of wisdom literature/ aphoristic literature, see: Gutas, Greek Wisdom Literature.

${ }_{13}$ See below, section 2.2.

${ }^{14}$ Al-Sijistānī, Muntakhab Șiwān al-Hikma.

15 Al-Andalusī, Kitāb Ṭabaqāt al-Umam, pp. 27-28. 
994, in al-Andalus) Kitāb Tabaqāt al-Ațibbā' wa-l-Hukamā'; Ibn alQifțī's (1172-1248, in Aleppo) Ikhbār al-'Ulamā' bi-Akhbār alHukama'; Ibn Abī Ușaybi'a's (1203-1270, in Cairo) 'Uyūn al-Anbā'fi Țabaqāt al-Ațibbā'; al-Bayhaqì's (d. 1170) Ta 'rīkh Hukamā' al-Islām; and al-Shahrazūrī's (13 ${ }^{\text {th }}$ century) Nuzhat al-Arwāh wa-Rawdat al-Afräh. ${ }^{16}$ The last two of these, however, consist mainly of wisdom sayings, and are less "biographical" in nature; Bayhaqi's dictionary in particular does not discuss early physicians, but starts with Hunayn b. Ishāq in the Islamic period, and then his son and followers. Earlier physicians, such as Galen, may be mentioned, but they do not receive their own entry. ${ }^{17}$ Thus, the three main sources for the individual characteristics of Greek doctors are Ibn Abī Ușaybi ${ }^{\circledR} a$, Ibn al-Qifți and Ibn Juljul.

Ibn Juljul was the personal physician of the Umayyad ruler al-Mu'ayyad bi-1lāh Hishām (r. 977-1009). He dedicated his dictionary to physicians, divided into chronological tabaqa $t$, or layers. ${ }^{18}$ It is hard to judge what motivated Ibn Juljul to write his dictionary. According to Balty-Guesdon, it was composed as a critique of the Amirid regime. ${ }^{19}$ However, such a critique does not appear as the focus of this book. Álvarez Millán, on the other hand, argues that Ibn Juljul wished to exhibit his medical knowledge. ${ }^{20}$ Ibn al-Qifți was a judge and an administrator in Aleppo, and his dictionary includes scholars from all avenues of science, including arithmetic, astronomy, philosophy, medicine, and astrology. ${ }^{21}$ He mentions Ibn Juljul as one of his sources, and cites or summarises parts of his dictionary. The author of the third dictionary,

${ }^{16}$ Ibn Juljul, Kitāa Tabaqāt al-Ațibbā'; Ibn al-Qifțì, Ikhbār al-'Ulamā'; Ibn Abī Ușaybi'a, 'Uyūn al-Anbā'; al-Bayhaqī, Ta'rìkh Hukamā' al-Islām; al-Shahrazūrī, Nuzhat al-Arwāh.

${ }^{17}$ For general information about and assessment of these texts as sources for the history of medicine see: Halaf al-Ḥamārna, "Muslim Historiography". See pp. 234-235 for al-Bayhaqi's period of interest.

${ }_{18}$ Dietrich, "Ibn Djuldjul”, $E I^{2}$, vol. 3, p. 755; Álvarez Millán, "Medical Anecdotes"; Balty-Guesdon, "Les Tabaqāt", pp. 49-59.

19 Manuela Marín demonstrates that the relationship between scholars and rulers in al-Andalus was rather tense. Scholars saw relations with rulers as corrupting and unfit for a pious man. Nonetheless, most scholars did have some relations with the court, though in some cases these were unofficial. During the Amirid period this relationship deteriorated, as scholars felt mistreated by the hajjib and were thus were less willing to take formal positions. For a survey of the relationship in al-Andalus see: Marín, "Inqibā 'an al-Sultānn".

${ }^{20}$ Álvarez Millán, "Medical Anecdotes".

${ }^{21}$ Dietrich, "Ibn al-Kifțị”, $E I^{2}$, vol. 3, p. 840. 
Ibn Abī Ușaybīéa, was a physician in the Nūrī hospital in Damascus and the Nāșirī hospital in Cairo. He quotes Ibn Juljul and Ibn al-Qifṭī; in fact, large parts of his book were copied from Ibn al-Qifțî's dictionary. ${ }^{22}$

The three dictionaries thus relate to one another in terms of materials and sources. Their authors also refer to similar medical and historical sources, such as treatises by Galen and Hippocrates, Abū Ma shar's Kitāb al-Ulūf, and al-Sijistānī's Siwān al-Hikma. ${ }^{23}$ Nevertheless, the three biographies also differ significantly from one another, both in terms of content and of structure. Each author chose to include and exclude specific material, while the structure of the biographies in each dictionary has implications for the arrangement of the information and the way in which it is to be understood. Rather than reproducing the same biographies, each composition has its own constructions and emphases.

Despite their distinct structures, all three dictionaries begin with the question of the origins of medicine, suggesting an interest in describing the development of medicine from its first appearance up to the time of each author. Ibn Juljul constructed his dictionary chronologically, according to the tabaqāt of his biographical subjects. His first entry is dedicated to Hermes, who is presented as the prophet of science, ${ }^{24}$ followed by two other figures also called Hermes, ${ }^{25}$ and then Asclepius. These four figures constitute the first tabaqa of people who discussed medicine and philosophy, and form a narrative of the transmission of medical science to humankind and to Muslims. ${ }^{26}$ Ibn al-Qifți's dictionary, by contrast, is organised in alphabetical order, and he begins by stating that he intends to discuss whoever has practiced science (unlike Ibn Juljul and Ibn Abī Ușaybiea, who dedicated their dictionaries to medicine alone). However, by identifying Hermes with the Arabic name of Idrīs, Ibn al-Qifți is able to discuss the biography of Hermes-Idrīs' and the origins of medicine at the beginning of his book while main-

22 Vernet, "Ibn Abī Ușaybi'a", $E I^{2}$, vol. 3, pp. 693-694.

${ }^{23}$ Abu Ma'shar's book is now lost, and is only available to us through quotations in other books, such as that of Ibn Juljul.

${ }^{24}$ Ibn Juljul, Kitāb Tabaqāt al-Ațibbā', p. 5.

${ }^{25}$ Hermes and his contribution to the cultivation of science in the Muslim world will be discussed further below.

${ }^{26}$ The second tabaqa refers to Greece, beginning with Hippocrates, and the third to Rome, in which Galen is located. 
taining alphabetical order. ${ }^{27}$ Like Ibn Juljul, Ibn Abī Ușaybi a also arranges his biographies alphabetically, and he shows a deep interest in the question of the origin of medical knowledge. Ibn Abî Ușaybi a regarded this kind of knowledge as having a divine source, and some of his introduction and most of his biography of Asclepius is dedicated to this subject. ${ }^{28}$

\subsection{Biographical dictionaries and Greek physicians}

The biographical dictionaries elaborate not only on the individuals who cultivated medicine, but also on the process that allowed humans to discover the art of medicine. The authors suggest several possibilities, but judge the most likely process to have been a transmission through a chain of eight important physicians, beginning with Asclepius and ending with Galen. This story is traced back to the treatise of Ishāq b. Hunayn, who in turn places its origin with Yahyà al-Nahwī, who probably lived in early seventh-century Alexandria and whose identity is unclear. ${ }^{29}$ Three of these eight names are of special significance: Asclepius, Hippocrates (the seventh name on the list) and Galen. They have detailed biographies in the dictionaries, and are depicted as "round" characters with Islamic religious and moral characteristics. By contrast, three other names, Asclepius II, Ghurās and Minūs, have not yet been identified by modern scholarship, and the biographical dictionaries give only a few details about them. Two more figures, Plato and Parmenides, are better known as philosophers, and they are rarely described as physi-

${ }^{27}$ Ibn Juljul and Ibn Abī Ușaybiea both discuss the identification of "Hermes" with Idris (taken to be the Arabic form of the name) and Enoch (the Hebrew form).

${ }_{28}$ Ibn Abī Ușaybi'a, 'Uyūn al-Anbā', pp. 15-19.

${ }^{29}$ Rosenthal, "Ishāq b. Ḥunayn's Ta'rịh al-Ațibbā'”. For a slight variation on this list see also al-Shahrazūiri, Nuzhat al-Arwāh, p. 274. The source for this story remains unclear. Whereas Rosenthal, for instance, accepts that the source was an Alexandrian Christian of the sixth century, Zimmerman argues that the story demonstrates a need to place medical knowledge within the timeline of monotheism. Such a need, he argues, was not a common interest in sixth-century Alexandria. Zimmermann, "The Chronology of Ishạa Ibn Hunayn". A similar theme appears in the illustrated epistle Kitāb al-Diryāq, the author and the time of writing of which are not clear. It is currently argued that it was written by an anonymous author in $10^{\text {th }}$-century Baghdad. As the text remains in manuscript form only we were unable to see it. The introduction of the book mentions nine important physicians who made significant contributions to the development of antidotes. The names on this list differ from the "list of the eight" (although Galen, for example, appears in both). Pancaroğlu, "Socializing Medicine". 
cians elsewhere. The biographical dictionaries do not elaborate on them, and give no specific details about their religious or moral behavior, and in some cases they do not even have a dedicated entry. ${ }^{30}$ This exclusion seems to have been a deliberate choice, since the authors could have drawn on Greek biographies for details that could serve to depict moral figures. It seems that in their effort to situate medicine within an Islamic framework, the authors of the dictionaries chose to avoid discussing religiously-problematic issues such as philosophy. ${ }^{31}$

We intend to show that the authors' construction of the origin of medicine demonstrates a particular approach to the cultivation of science and medicine and to intellectual discourse regarding the validity of scientific knowledge. Further, an analysis shows that this construction and this discourse represent an attempt to interpret the position of science in general and of medicine in particular for an Islamic society. In other words, they give the authors' point of view regarding knowledge and its possible origins. Once the origin is constructed, the story is developed within an Islamic framework.

\section{Usage and meaning of Islamic and prophetic language}

The proximity of medicine to prophecy is not a unique perspective of Muslim writers; according to a statement attributed to Hippocrates, "Medicine and prophesy are very closely related, since of the two arts Apollo is the single father." 32 In Islamic biographical dictionaries, proximity is created through the use of religious language in the biogra-

${ }^{30}$ E.g., Ibn al-Qifți has no entry on Parmenides. His entry on Plato is considerably more developed than the entries in the other dictionaries, although it focuses only on Plato's contribution to philosophy (Ibn al-Qifți, Ikhbār al-'Ulamā', p. 68). We hope to further investigate the whole list in a future study.

${ }^{31}$ For Greek philosophers in Islam see for example, Alon, Socrates in Medieval Arabic Literature.

32 Jouanna, however, notes that this statement probably dates from a later time, since Asclepian healing, which included working miracles, did not accord with the Hippocratic principle of diagnosis through observation and logic. Jouanna, Hippocrate, pp. 3-25. A similar idea can also be found in Christian communities, where Hippocrates is regarded as a man, but a special one: as God Almighty saw the difficulty that humans were facing, He brought Hippocrates to the light. For further elaboration on this issue and the conception of medicine as prophecy see: Crisciani, "History, Novelty, and Progress". We would like to thank Naama Cohen for pointing out the importance of this paper. 
phies of the three Greek doctors. Although the authors of these dictionaries do not claim that the physicians themselves were Muslims, the language used is distinctively Islamic, and the terms used associate these doctors with prophetic characteristics and figures, including the Prophet Muhammad himself.

\subsection{Sources of knowledge}

According to all three dictionaries under consideration, Asclepius' knowledge stemmed from revelation: ilham and wahy. ${ }^{33}$ This terminology at once echoes the Greek myth of Asclepius as learning medicine from divine beings, while also locating Asclepius in an Islamic context: the term wahy specifically denotes divine inspiration, and is usually used in the context of the revelation of the Qur'ān to Muhammad and other prophets. ${ }^{34}$ This is clearly stated in al-Shahrazūrī, who describes Asclepius as "al-Nabi al-Hakim" - the prophet-physician. AlShahrazūri further comments, however, that Asclepius found the knowledge of medicine in a temple of the sun. This comment seems to relate to the Greek view that medicine originated with the sun-god Apollo. It might also echo the idea of knowledge as buried treasure, as discussed below. ${ }^{35}$

Asclepius is also described by Ibn Abī Ușaybiea as a messenger of God whose mission is to teach humanity medicine: ba athahu Allāh $f a-$ 'allama al-nās al-tibb ${ }^{36}$ — not unlike prophets whom God sends to teach humanity about religion. Ibn Juljul's concluding remark links Asclepius - as well as medicine - with prophethood in the Muslim context:

All the information that I have quoted earlier demonstrates that the beginning of the study of medicine and philosophy was in revelation and God-given inspiration

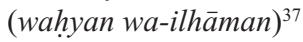

${ }^{33}$ Ibn Juljul, Kitāb Ṭabaqāt al-Ațibbā', p. 9, 13; Ibn al-Qifțī, Ikhbār al-'Ulamā', p. 9; Ibn Abī Ușaybi'a, 'Uyūn al-Anbā', pp. 15-16.

${ }^{34}$ On the difference between ilhām and wahy, see: MacDonald, "Ilhām", $E I^{2}$, vol. 3,

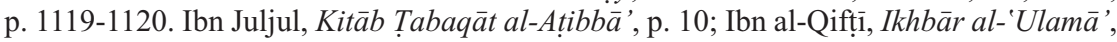
p. 9; Ibn Abì Ușaybi'a, 'Uyūn al-Anbā', p. 16.

${ }_{35}$ Al-Shahrazūrī, Nuzhat al-Arwāh, pp. 80-81.

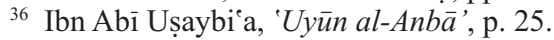

${ }^{37}$ Ibn Juljul, Kitāa Ṭabaqāt al-Ațibbā', p. 13. 
However, Asclepius also had a teacher, named Hermes. While Ibn Juljul and al-Shahrazūrī identify this teacher as Hermes the Egyptian, ${ }^{38}$ Ibn al-Qifți and Ibn Abī Ușaybi'a argue that this teacher was the first Hermes. ${ }^{39}$ This particular Hermes is identified with the Qur'annic prophet Idrīs, and with the antediluvian Biblical figure of Enoch son of Jared. According both to Ibn al-Qifți and to Ibn Abī Ușaybi ${ }^{e} a{ }^{40}$ Hermes/Idrīs was the source of all scientific knowledge. He was the first to cultivate medicine and other sciences, and he received his knowledge through revelation. ${ }^{41}$ However, whereas Ibn Juljul refers to Hermes as the prophet of science, ${ }^{42} \mathrm{Ibn}$ Nadim refers to Hermes only as the author of books in astronomy. This indicates that a close relation between prophethood and medicine, or with sciences in general, is not selfevident from the biographies of the three doctors. ${ }^{43}$ Further, Ibn Abi Ușaybi a is not clear as regards whether the revelation was received by Asclepius or by Hermes. ${ }^{44}$

Similarly, Hippocrates' sources of knowledge, as the seventh link in the chain, are also not very clear. All three authors, as well as alShahrazūrī, agree that medical knowledge was transmitted through the family of Asclepius, and was restricted to his family. For this reason, probably, the biographies discuss the relationship of Hippocrates to Asclepius - the first link of the chain - and, consequently, to antediluvian knowledge. While according to Ibn Juljul, Hippocrates was of the family of Asclepius, ${ }^{45} \mathrm{Ibn}$ al-Qifți argues that this could not have been

38 Al-Shahrazūrī, Nuzhat al-Arwāh, pp. 80-81; Ibn Juljul, Kitāb Ṭabaqāt al-Ațibbā', p. 9. According to Ibn Juljul, this Hermes lived after the Flood and specialised, among other things, in poisons.

39 Ibn al-Qifṭī, Ikhbār al-'Ulamā', p. 8; Ibn Abī Ușaybi'a, 'Uyūn al-Anbā', p. 16.

40 Ibn al-Qifțì, Ikhbār al-'Ulamā', p. 1ff.; Ibn Abī Ușaybi a, 'Uyūn al-Anbā', p. 16 ff.

41 The biography of Hermes, the identification with Idrīs, and the revelation of science is beyond the scope of the present paper. For his biographies see: Ibn Juljul, Kitāa Tabaqāt al-Ațibbā', pp. 5-6; Ibn al-Qifțī, Ikhbār al-'Ulamā', pp. 1-6; Ibn Abī Ușaybi'a, 'Uyūn alAnb $\bar{a}$ ', pp. 4, 16-17. See also Y'ūcesoy, "Translation as Self-Consciousness". For a discussion regarding Idrīs, and how knowledge of Hermes or Enoch could have reached Muslims, see: Van Bladel, The Arabic Hermes. The idea that Idrīs/ Hermes was the source of medical knowledge appears also in modern Islamic literature. See for instance: Ebrahimnejad, "The Development of Galenic-Islamic Medicine". Ebrahimnejad quotes $19^{\text {th }}$ century Iranian scholars.

${ }^{42}$ Ibn Juljul, Kitāb Tabaqāt al-Ațibbä', p. 5.

${ }^{43}$ Ibn al-Nadīm, Fihrist, p. 267.

${ }^{44}$ Ibn Abī Ușaybiea, 'Uyūn al-Anbā', p. 19.

45 Ibn Juljul, Kitāb Ṭabaqāt al-Ațibbā', p. 16. 
the case, since Asclepius lived before the Flood, of which only the descendants of Noah survived. Therefore none of the descendants of Asclepius could have survived, and Hippocrates was instead the disciple of Heracles, and a descendant of Asclepius II. ${ }^{46}$ Al-Mubashshir b. al-Fātiq solved the problem in an interesting way, stating that Hippocrates was a descendant of the first Asclepius, but his teacher was Asclepius II ${ }^{47}$ Ibn Abī Ușaybi a suggests another possibility, according to which Hippocrates was a descendant of Asclepius through his paternal lineage and of Heracles from his maternal lineage; he received his medical knowledge from his father. ${ }^{48}$

The association between Hippocrates and Asclepius, and especially the attribution of the knowledge of Hippocrates to an antediluvian source, perhaps parallels the general interest of religious scholars ('ulam $\bar{a}$ ') in knowledge as treasure, buried books and waiting-to-be-discovered prophecies. ${ }^{49}$ For example, in the hadith literature we find that during the occupation of Tustar the Muslim soldiers found the grave of the Prophet Daniel, with his preserved body and a book of Muslim history. Similarly, it is said that in Wādī al-Qurā the Muslims found under a stone the body of al-Hārith b. Shu ayb al-Ghassānī, the messenger of the prophet Shu'ayb to the people of Midian, again buried with a book. ${ }^{50}$

Galen's education is much clearer. The authors of the dictionaries had fewer disagreements in this matter, possibly because Galen himself left detailed autobiographical information. ${ }^{51}$ The biographies discuss his teachers and the subject-matter of his education: mathematics, phi-

${ }^{46}$ Ibn al-Qifți, Ikhbār al-'Ulamā', p. 90. Interestingly, one of Idrīs's roles was to find a way to preserve scientific knowledge through the time of the Flood. Ibn al-Qiftī, Ikhbār al- 'Ulamā', p. $1 \mathrm{ff}$. Ibn Juljul, Kitāb Ṭabaqāt al-Ațibbā', pp. 5-6; Ibn Abī Ușaybi'a, 'Uyūn al-Anba', p. $16 \mathrm{ff}$.

47 Al-Mubashshir b. Fātiq, Mukhtār al-Hikam, p. 44. See also al-Shahrazūrī, Nuzhat al-Arwāh, p. 196, giving the name Askalyīs al-thānī. However, this name is also mentioned instead of Asclepius II in the line of eight physicians.

${ }^{48}$ Ibn Abī Ușaybi'a, 'Uyūn al-Anbā', p. 24.

49 Yūcesoy, "Translation as Self-Consciousness", p. 16.

${ }^{50}$ Wādī al-Qurā ('the wādì of villages') — a region of several valleys in Northern Hijāz. It is said that in ancient times this area was inhabited by the people of ' $\bar{A} \mathrm{~d}$ and Thamūd. Lecker, "Wādī 1-Kurā”, $E I^{2}$, vol. 11, pp. 18-19; al-Bayhaqī, Dalā'il al-Nubuwwa, pp. 1, 381-382; al-Majlisīi, Bihāar al-Anwār, p. 12, 383-384.

51 All of our information about Galen comes from this own writing. However, Nutton argues that despite the total silence about Galen among Latin medical writers before the fifth century, his importance in the Greek part of the Roman Empire, both as a philosopher and as a doctor, is testified to through the few references to him made by his contemporaries, 
losophy, logic, and medicine. They also discuss at length his love of knowledge and learning and his vast acquaintance with various disciplines, and they mention that he traveled in pursuit of medical knowledge and herbs. When Ibn Abì Ușaybi'a and al-Shahrazūrī say in this context that Galen sâfara fi talab al-'ilm, they use the same phrase that is usually used to describe the travels of hadith scholars in search of Muhammad's prophetic traditions. ${ }^{52}$

\subsection{Attributed characteristics and actions}

As a person, Asclepius is portrayed as having qualities that accord with the Islamic model of appropriate behavior. He is depicted as having his own way (sira) of purity, an allusion to the sira (biography, way of life) of the prophet Muhammad, and the traits ascribed to him - humility, piety, morality, purity of nature, staying away from evil, and fear of God - identify him as pure, moral and pious as according to Islamic criteria.$^{53}$ According to al-Shahrazūrī, during Asclepius's visit to Persia, a group of people asked for his advice. He reproached them for preferring this world to the hereafter, and urged them to listen to the preaching of the messenger of God, Idrīs. ${ }^{54}$ This description adds a Sufi touch to his image, and has him acknowledge the priority of prophecy over medicine. Another title that is bestowed upon him is ima am al-tibb, which is reminiscent of the religious function of the leader of prayer (imām al-șalāt) in Islam. ${ }^{55}$

which confirm his own estimate of his achievements. Nutton notes the writings of Alexander of Aphrodisias, a strong critique of Galen; a theological pamphlet by Christian heretics of about 210, and Athenaeus's Deipnosophists, written in the beginning of the third century. All of these relate, he says, to Galen as "a man of importance and reputation, for philosophy as well as for medicine, at least in the Greek world" (324). Nutton, "Galen in the Eyes".

${ }^{52}$ See, for example, Al-Qurtubì, Tafsìr, vol. 5, pp. 350-351. This phrase can also be found in biographies of muhaddithūn, who travelled in search of prophetic tradition. See for example, Ibn Hajar, Tahdhīb al-Tahdhìb, vol. 1, p. 62; vol. 3, pp. 111, 347; vol. 4, pp. 75; Ibn Abì Ușaybi'a, 'Uyūn al-Anbā', p. 32; al-Shahrazūrī, Nuzhat al-Arwāh, p. 274; Ibn Juljul and Ibn al-Qifțī discuss Galen's travels, but do not use this phrase.

${ }_{53}$ Ibn Juljul, Kitāb Tabaqāt al-Ațibbā', pp. 11-13; Ibn al-Qifțī, Ikhbār al-'Ulamā', p. 9; Ibn Abī Ușaybiea, 'Uyūn al-Anbā', p. 16.

${ }_{54}$ Al-Shahrazūrī, Nuzhat al-Arwāh, pp. 80-81. See also the discussion below regarding Galen for further reference to this anecdote.

${ }_{55}$ For further elaboration see: Abbou Hershkovits, "Asclepius in Biographical Dictionaries". 
Asclepius is also said to have had a spiritual (ruḩ̄n̄i) birth. This, along with God's words to him, that He would rather call him an angel than a human being, echoes the deification of Asclepius in Greek sources. ${ }^{56}$ In the Muslim context, however, this motif is given a monotheistic interpretation: once his birth is depicted as "spiritual", Asclepius is located as closer to Jesus than to Apollo; and rather than join the Olympic pantheon, he is associated with the angels. Al-Bìrūni (d. 1048) also mentions the possibility that medicine was the result of prophecy, though he does not use the word wahy, only ilhamm. ${ }^{57}$ Another possibility raised by al-Bìrūnì is that Asclepius was Adam's son, and that Adam was the source of Asclepius' medical knowledge.

The end of Asclepius' life is as obscure as his origin. It is agreed by all three authors, as well as al-Shahrazūrī and al-Bīrūnī, that he never died, but was raised to heaven by God (Allāh ta' àlā rafa'ahu) in a col-

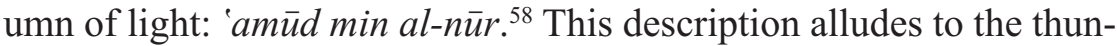
derbolt that Zeus used to kill Asclepius (or, according to other versions, to turn him into a god), ${ }^{59}$ but an additional monotheistic connotation is the column of fire that accompanied the children of Israel in the desert (Exodus 13:21-22). Manzalaoui further points out the parallel between the ascension of Asclepius and the ascensions both of Jesus (who, according to the Qur'ān, was not crucified, but raised by God to heaven $)^{60}$ and Heracles, who "rose from a funeral pyre to heaven." ${ }^{11}$ The identification of Enoch-Idrīs-Hermes as the teacher of Asclepius

56 Ibn Juljul, Kitāb Ṭabaqāt al-Ațibbā', p. 10; Ibn al-Qifțī, Ikhbār al-'Ulamā', p. 9; Ibn Abī Ușaybiea, 'Uyūn al-Anbā', p. 16. See also al-Shahrazūrì, Nuzhat al-Arwāh, pp. 80-81.

${ }_{57}$ Al-Bīrūnī, Risāla fi fihrist, pp. 25-26, 29.

58 Ibn Juljul, Kitāb Tabaqāt al-Atibbā', p. 10; Ibn al-Qifțī, Ikhbār al- 'Ulamā', p. 9; Ibn Abī Ușaybie'a, 'Uyūn al-Anbā', p. 16; al-Shahrazūrī, Nuzhat al-Arwāh, pp. 80-81; alBìrūnì, Risāla fi fihrist, pp. 25-26. Manzalaoui notes that the pillar of light and the comparison with an angel also both appear in relation to Aristotle. However, he states that these stories were originally told of Asclepius, and only later were transferred to Aristotle. Manzalaoui, "The Pseudo-Aristotelian Kitāb Sirr al-Asrār", see esp. pp. 189-191. See also Ibn Juljul, Kitāb Tabaqāt al-Atibbā', p. 28.

59 It is said that Zeus killed Asclepius after the latter used his unique medical skills to return a person from the dead. Fink, Who's Who, (Hebrew), p. 66; Edelstein and Edelstein, Asclepius Collection, vol. 1, p. 108. This episode bears some resemblance to the myth of Prometheus, who granted humanity with divine knowledge (as well as the gift of fire), and was punished for that by Zeus. Aeschylus, Prometheus Bound, lines 660-740; Fink, Who's Who, p. 224.

60 Qur'ān, 4, 157-158.

61 Manzalaoui, "The Pseudo-Aristotelian Kitāb Sirr al-Asrāor", p. 191. 
is also of interest in this context since, according to Gen. 5:24, Enoch also never died but was "taken by God" to heaven. ${ }^{62}$ Similarly, according to the Qur'ān Idrīs did not die but was "raised to a high place". ${ }^{63}$ This identification thus also contributes to the location of Asclepius - and his teacher - in an Islamic context.

Ibn Juljul attributes to Galen the statement that whoever wishes to learn Hippocrates' knowledge (man talaba 'ilm buqarāt ) must follow his example in doing good and wishing for good virtues, as well as moving away from villainy (fal-ya'takhidh hadhwahu fi l-fadl wa-lraghb fi l-fadìla wa-tajannub al-radhīla). Similarly, al-Sijistānì records Hippocrates' command to his students to do good to people (istina $\bar{a}^{\prime}$ alma'rüfilayhim). Both thematically and literally, these sayings connote with one of the most fundamental laws of Islam, that of "commanding the good and forbidding evil". ${ }^{64}$

Most telling is the single anecdote that is attached to his biography, and which appears in all three dictionaries. According to this anecdote, Hippocrates admitted to his students that "I do like fornication; however, I control my urge." ${ }^{\prime 65}$ This episode seems surprising at first. However, it is reminiscent of a quite prominent story in the hadith literature about the personal demon (shaytān) of the Prophet Muhammad. According to this story, the Prophet Muhammad said that all human beings have a demon (shaytān). When asked about himself, the Prophet confirmed that he, too, had a demon; however, with the help of God, he overcame it, and it eventually converted to Islam. ${ }^{66}$ These anecdotes respectively glorify the characters of Hippocrates and Muhammad; by overcoming a weakness, both individuals demonstrate their moral su-

62 Genesis, 5, pp. 21-24 - "And Enoch lived sixty and five years, and begat Methuselah: And Enoch walked with God after he begat Methuselah three hundred years, and begat sons and daughters: And all the days of Enoch were three hundred sixty and five years And Enoch walked with God: and he was not; for God took him." The Bible: Authorized King James Version, R. Carroll and Prickett (eds.), Oxford and New-York, 1997.

${ }_{63}$ Qur'ān, 19, 56-58.

${ }^{64}$ Ibn Juljul, Kitāa Tabaqāt al-Ațibbā', p. 17. For the historical development of the expression "command the good and forbid the evil" see: Cook, Commanding Right .

${ }^{65}$ Ibn Abī Ușaybiea, 'Uȳun al-Anbā', p. 21; Ibn Juljul, Kitāb Ṭabaqāt al-Ațibbā', p. 17; Ibn al-Qifțī, Ikhbār al-'Ulamā', pp. 91-93.

${ }^{66}$ Muslim b. al-Hajjāj Abū l-Husayn al-Qushayrī al-Naysābūrī, Sahìh Muslim, vol. 4, p. 2168; al-Nasā' '̄, al-Sunan al-Kubrāa, vol. 5, p. 287; Ahmad b. Hanbal Abū 'Abdallāh alShaybānī, Musnad al-Imām, vol. 6, p. 115; al-Tirmidhī, al-Jāmi' ail-Ṣahìh, vol. 3, p. 475; Ibn Hibbān, Șahịh, vol. 14, p. 326. See Allouche, "Between the milk and the froth", pp. 61-62. 
periority and spiritual strength. According to Ibn Juljul, the story about Hippocrates demonstrates his merits and moral standing. ${ }^{67}$

Hippocrates is also depicted as an ascetic (nāsikan), demonstrated, for example, through al-Shahrazūrì's description of him as a person who withdrew from the world (tazahhada) and frequently fasted. ${ }^{68}$ Furthermore, he is described as a well-known, quick-witted imām (imām fahim ma'rüf), ${ }^{69}$ an outstanding and even a divine person (fädilan muta'allihan).$^{70}$ The inclusion of this last epithet in an Islamic context seems surprising, since in Islam even the Prophet Muhammad is regarded as no more than a human being: a perfect man (al-insān al$k \bar{a} m i l)$, but not divine. Therefore, it is likely that this epithet of Hippocrates reflects references to him in the Greek sources as "the divine Hippocrates".

Further, Hippocrates is said to have refrained from any interaction with royalty. He refused to treat the Persian ruler, who was the enemy of the Greeks, and rejected the latter's offers of generous gifts. Hippocrates did agree, however, to treat two Greek kings, whose behavior was moral (hasanay al-sira); once they were healed, he left the court. ${ }^{71}$ The use of the pregnant term sira in this context again seems to imply to the life of the Prophet Muhammad (sirrat al-rasūl). A somewhat different (although not necessarily contradictive) approach is represented through a statement that is recorded by both al-Shahrazūrì and al-Sijistānì, claiming that Hippocrates used to charge fees only from rich people. ${ }^{72}$

A similar trait is attributed to Galen, the eighth and final physician in the chain. He, too, is said to never have taken anything from kings: wa-lam ya'khudh min ahad min al-mulük shay'an wa-là wäkalahum wa-lā dākhalahum. ${ }^{73}$ However, according to his own writings, Galen did accept presents, although he does say that he did not ask to be paid for his services. Moreover, he also served the Emperor Marcus Aurelius

${ }^{67}$ Ibn Juljul, Kitāa Tabaqāt al-Ațibbā', p. 17.

${ }_{68}$ Al-Shahrazūrī, Nuzhat al-Arwāh, pp. 199-200.

${ }^{69}$ Ibn al-Qiftīi, Ikhbār al-'Ulamā', p. 90.

${ }^{70}$ Ibn Juljul, Kitāb Ṭabaqāt al-Ațibbà', pp. 16-17; Ibn al-Qifțī, Ikhbār al-'Ulamā', pp. 90-93. See also Ibn Abī Ușaybi'a, 'Uyūn al-Anbā', p. 23.

${ }^{71}$ Ibn Juljul, Kitāa Tabaqāt al-Ațibbā', p. 17; Ibn al-Qifțī, Ikhbār al-'Ulamā', p. 91. See also al-Sijistānī, Muntakhab Siwà̄n al-Hikma, p. 75.

${ }^{72}$ Al-Shahrazūrī, Nuzhat al-Arwāh , p. 200; al-Sijistānī, Muntakhab Șiwān al-Hikma, p. 74.

${ }^{73}$ Ibn Juljul, Kitāb Ṭabaqāt al-Atibbā', p. 44. See also Ibn al-Qifțī, Ikhbār al-'Ulamā', p. 125.

Al-Qantara XXXIV 1, 2013, pp. 35-63 ISSN 0211-3589 doi: 10.3989/alqantara.2013.002 
and his family. This discrepancy is thus an example of how the authors of the dictionaries used a transmitted detail and gave it an Islamic interpretation, perhaps in an attempt to create a correlation between the biographies of Galen and Hippocrates. The trait attributed to Galen is also characteristic of many 'ulam $\bar{a}$ ', who refused official appointments and royal presents, so as to preserve their independence and avoid compromising their beliefs; the companions of kings were considered morally corrupted. ${ }^{74}$ Galen is thus painted in the colors of Islamic piety, as a person who shuns rulers.

Galen is also referred to as khatim al-atibbā' - the seal of the doctors. ${ }^{75} \mathrm{He}$ is also thus described by Mubashshir b. Fātiq. ${ }^{76}$ This phrase echoes khätim al-anbiy $\bar{a}$ ', the seal of the prophets, which is an epithet of the Prophet Muhammad ${ }^{77}$ probably derived from Q 33:40, where the Prophet is called khätim al-nabiyyin, the last prophet in the chain of prophets. ${ }^{78}$ As we have seen, the biographical dictionaries consider Asclepius, Hippocrates and Galen to be part of a list of eight doctors, each important for his own time. However, the followers of each doctor corrupted the knowledge that was imparted to them, and almost brought medicine to destruction, until the next great physician appeared..$^{79}$ As the final link in the chain, Galen brought medicine to perfection.

74 Lapidus, A History of Islamic Societies, p. 190.

75 Ibn al-Qifțī, Ikhbār al-'Ulamā', p. 12; Ibn Abī Ușaybi a, 'Uyūn al-Anbā', p. 71; alShahrazūrī, Nuzhat al-Arwāh, p. 274.

76 Al-Mubashshir b. Fātiq, Mukhtār al-Hikam, p. 288.

77 For example, Ibn Sa d, al-Ṭabaqāt al-Kubrā, vol. 1, p. 163; al-Suyūṭì, Kifāyat alTălib, vol. 1, p. 24.

78 Most commentaries explain khätam/ khätim al-nabiyyìn as 'the last prophet'. Nevertheless, the primary meaning of this phrase in the Qur'ān is uncertain. Yohanan Friedmann argues that classical Arabic literature preserved material which suggests that in the first centuries of Islam other meanings, such as 'the best prophet', or 'he who authenticates and verifies the former prophets', were also prevalent. He suggests that it was not before the second half of the $10^{\text {th }}$ century that khätam al-nabiyyin as 'the last prophet' became an article of faith in Sunnī Islam, and other meanings were repressed. Friedmann connects this development with the emergence of (false) prophetic claimants, especially during the ridda period. Friedmann, Prophecy Continuous, pp. 53-82. According to Powers, 'the last prophet' dogma also served the Muslim community in holding back possible prophetic claims by the descendants of Zayd, Muhammad's adopted son. Thus Powers dates the prevalence of this meaning to the first century of Islam. Either way, all biographical dictionaries used in the present study date from the late $10^{\text {th }}$ century onwards, a time by which khätim al-atibba ' (or al-anbiy $\bar{a}$ ') was probably generally understood as 'the last doctor/ prophet'. Powers, Muhammad is not the Father, pp. 50-61.

79 Rosenthal, "Ishāa b. Hunayn". 
Muhammad, who is the last prophet in the chain of prophets, is considered as al-insān al-kāmil, the perfect human being who corrected the revelation of his predecessors and whose message cannot be corrected any further.

Other epithets given to Galen also allude to terms that relate to the Prophet Muhammad, such as imām al-ațibba $\bar{a},{ }^{80}$ which parallels imām al-mursilin - the leader of prayer for the messengers of God (Muhammad's role on the Day of Judgment) ${ }^{81}$ It is also said that during his Nocturnal Journey (al-isra $\bar{a}$ ') the Prophet was the imām of the prophets and messengers (sallä bi-l-nabiyyin wa-l-mursilìn imäman). ${ }^{82}$ The description of Galen as holding the key of medicine- miftăh al-tibb ${ }^{83}$ - connotes the description of the Prophet Muhammad as holding the keys to the treasures of the world - mafâtì $k$ khaza 'in al-ard /al-duny $\bar{a} .^{84}$

Ibn Abī Ușaybi'a also relates the story of how Galen became a doctor, based on Galen's own writings ${ }^{85}$ Galen was first dedicated by his father to study mathematics, then philosophy and logic; but Galen's father then had a dream $\left(r u^{\prime} y \bar{a}\right)$, in which he was instructed to give Galen a medical education. ${ }^{86}$ Ibn Abì Ușaybia's's choice of words in retelling the story is quite meaningful, as dreams often serve as literary and theological tools. ${ }^{87}$ The word " $r u$ ' $y \vec{a}$ ", in addition to meaning "a dream", can also mean "a vision", or "a divine revelation" ${ }^{88}$ Thus, the inclusion of this story and this term in the Islamic biography of Galen contributes to the reconstruction of Galen's image as an Islamic figure, draws attention to the vocational nature of Galen's occupation, and empha-

${ }^{80}$ Ibn al-Qifțī, Ikhbār al-'Ulamā', pp. 122-123; Ibn Juljul, Kitāb Ṭabaqāt al-Ațibbāa', p. 32 .

${ }^{81}$ Al-Haythamī, Majma' al-Zawà' 'id, vol. 8, p. 284.

82 Al-Ṭabarī, Tafsìr, vol. 15, p. 3-5.

${ }^{83}$ Ibn al-Qifțī, Ikhbār al- 'Ulamā', pp. 122-123; Ibn Juljul, Kitāb Ṭabaqāt al-Ațibbā', p. 32 .

${ }^{84}$ Ibn Ḥibbān, Șahịh, vol. 14, p. 277; al-Muttaqī al-Hindī, Kanz al-'Ummāl, vol. 11, p. 411. Compare with Revelation 1:18, where Jesus declares: "I am he that liveth and was dead... and have the keys of hell and of death". Delbanco, The Death of Satan, p. 25.

${ }^{85}$ Hankinson, "The man and his work", pp. 1-33.

${ }^{86}$ Ibn Abī Ușaybi'a, 'Uyūn al-Anbā', p. 71.

87 According to Reynolds, a dream dreamt by the parent is a common dream-motif in Islamic autobiographies. These dreams are often interpreted as heralding the birth of a child, but they might also determine the child's name or occupation. In this context, Reynolds mentions the example of Galen's father, whose dream determined Galen's medical education. Reynolds, "Symbolic Narrative", pp. 261-286, note 39.

${ }^{88}$ Fahd, "Ru'yā", $E I^{2}$, vol. 8, pp. 645-648. 
sises the proximity between divine mission and the medical profession in general.

Finally, all three dictionaries claim that Galen was a contemporary of Jesus, whereas according to al-Shahrazūrì, Galen lived two hundred years after Jesus. ${ }^{89}$ The dictionaries even add that Galen gave Jesus an oath of allegiance (bay'a). Al-Bayhaqi records this story in the biography of a physician named Abu l-Faraj. The latter considered himself to be a descendant of Paul the Apostle. Paul, according to this anecdote, was Galen's nephew, the son of Galen's sister. When Jesus was sent to earth, Galen was too old to go to see him. Thus he sent Paul to Jesus with a letter, in which Galen gave Jesus a bay'a, acknowledged his prophetic status, and asked Jesus to heal Paul's soul. As a result, Paul became one of the disciples. ${ }^{90}$

The term bay'a appears, for example, in reports about Arab tribes who accepted Islam and gave the Prophet Muhammad an oath of allegiance. The parallel is further emphasised by Islam's recognition of Jesus as a prophet. As well as acknowledging Jesus' powers of spiritual healing, this anecdote demonstrates the submission of medicine to Islam. A similar idea can be detected in an anecdote recorded by AlShahrazūrī in reference to Asclepius' visit to Persia. Here, too, medical knowledge is presented as secondary to the teaching of the religious messenger. ${ }^{91}$

The correspondence between Galen and Jesus situates Galen as part of a monotheistic world, having a unique association with an important prophet. Though not much is said about Galen, in terms of his moral behavior or religious beliefs, al-Bayhaqi's anecdote clearly presents him as a believer in Jesus' message. Moreover, part of their correspondence relates to the role of physicians; according to Jesus, physicians are needed to preserve the health of the believers. At the same time, Galen is not capable of healing his nephew Paul; but by acknowledging Jesus' power, and his greater skills, a sort of bay'a is achieved. ${ }^{92}$

This claim contradicts the writings of Galen himself, with which the Muslim authors were well acquainted. Zimmerman suggests that

${ }^{89}$ Ibn Juljul, Kitāb Tabaqāt al-Ațibbā', p. 32; Ibn al-Qifțī, Ikhbār al-'Ulamā', p. 123; Ibn Abī Ușaybi'a, 'Uyūn al-Anbā', p. 62; al-Shahrazūrī, Nuzhat al-Arwāh, p. 274.

90 Al-Bayhaqī, Ta'rīkh Hukamā' al-Islām, p. 45.

91 Al-Shahrazūiñ, Nuzhàt al-Arwāh, pp. 80-81.

92 Al-Bayhaqī, Ta'rìkh Hukamā' al-Islām, p. 45. 
the association of Galen with the time of Jesus should not be understood literally; rather, it should be related to the concept of the chain of doctors, which, as we have seen, correlates with the Islamic idea of the chain of prophets, silsilat al-anbiy $\bar{a}$ ': with Asclepius (the first doctor) as a contemporary of Adam (the first prophet) and Galen (the seal of the doctors) as the contemporary of Jesus (the last prophet before Muhammad and a significant prophet, who brought a book). In this way a historical framework is created through which medicine and monotheism can be correlated. ${ }^{93}$ Zimmerman's interpretation is further supported by a frequently-made distinction in which Moses lived in an age of magic, and therefore his miracles were magical in character; Jesus lived in an age of medicine, and therefore his miracles were to do with medicine; and Muhammad lived in an age of rhetoric, thus his miracle (the Qur'ān) was one of rhetoric. ${ }^{94}$

\section{Greek physicians, Muslim biographies}

Once transmitted and translated, texts go through transformations. The biographies discussed in this paper illustrate this process, and also tell us a story. It is here argued that these biographies of Greek physicians should be read as elements of a narrative that describes the story of science: where science originated, when was it first cultivated, and its position vis-à-vis other branches of knowledge. Though we are not in a position to construct the whole narrative, it is evident that the Islamic biographies of Greek physicians are different from Islamic biographies of other Greek scholars. We do not encounter attempts to associate astronomers ${ }^{95}$ with prophets, or with monotheism. There is almost no other Greek scholar whose lifetime is measured against Adam or any other religious figure. ${ }^{96}$ Even among physicians these

93 Zimmermann, “The Chronology of Ishāa Ibn Ḥunayn”, pp. 324-330.

${ }^{94}$ See for example: Ibn Kathīr, Abū l-Fidā' Ismà̄î̀l, Tafsìr Ibn Kathīr, Beirut, 1401 A.H. [1980 C.E.], 1, 365-366. Ibn Ḥajar, Fath al-Bārī, vol. 9, pp. 6-7.

${ }_{95}$ Though in one interesting and unique case, al-Ghazāli argued that the knowledge of the movement of the stars required observations that were longer than the lifespan of humankind. He therefore concluded that the knowledge of the circulation of the stars must have been derived with divine aid. Menn, "The Discourse on the Method", pp. 141-191.

${ }^{96}$ Except for Socrates. See: Alon, Socrates. 
three figures are represented in a distinct way by the authors of the biographical dictionaries.

By inserting particular details and omitting others, the authors of the three dictionaries created narratives that reflected the way in which each perceived medicine and its sources, which they associated with antediluvian prophecy. This affiliation bestows credibility and gives authority to medical knowledge. At the same time, the authors make a statement about the possibilities open to humankind in the search of valid knowledge while also associating the knowledge and practice of medicine with the proper Islamic way of life.

These features are further enhanced by characteristics and traits associated with each physician. The choices made by the authors with regard to what to include and the order in which the material is presented gives the physicians a particular image, as well as specific expectations about knowledge, behavior, and morals. The authors used models borrowed from the monotheistic Islamic world, models that their audiences could probably recognise and with which they could identify.

One might ask about the motivations that led the authors to portray medicine and Greek physicians in such a manner. Were they facing critiques that threatened the practice of medicine? Was the list of eight physicians a well-established narrative regarding medicine that these late sources were just repeating? It seems that the answer to both suggestions is: "well, not exactly".

Of all branches of science, medicine faced least criticism during this period..$^{97}$ Therefore, it seems that there was not much of a need to answer a critique or to formulate apologetics. Nor was this portrayal of medicine a well-established narrative. Christian sources, for instance, had a different approach to Greek medicine and to medical figures. Asclepius and his order were considered to be competitors of Christian healing, and were highly criticised..$^{98}$ What might be considered as the Islamic equivalent of Christian healing is tibb al-nabi (prophetic medicine); that is, medical treatment based on Muhammad's sayings.

${ }_{97}$ One fascinating example is al-Ghazālì's approach to medicine. Al-Ghazālī, who was most identified with the exclusion of the ancient sciences from the madarris, nevertheless accepted medicine and associated it with divine guidance. Furthermore, according to Menn, al-Ghazālì himself (al-Munqidh) used Galen's autobiography as a model when he came to write his own autobiography. Menn, "Intellectual Autobiography", pp. 141-191.

${ }_{98}$ Temkin, Hippocrates, p. 70 ff. For Pagan arguments for the divinity of medicine see also: Menn, "Intellectual Autobiography", f.n. 33. 
However, Irmeli Perho, who has examined the development of this genre, its sources and motivations, argues that its aim was "to transfer the medical authority from Galen to the Prophet. But [...] not to discard Galen or deny the merits of Græco-Islamic medicine." ${ }^{99}$ Furthermore, the most structured texts dealing with the Prophet's medicine, presenting principles and suggesting remedies according to the Prophet's sayings, date from the latter part of the $13^{\text {th }}$ and $14^{\text {th }}$ centuries, a period later than the texts under examination in this paper. It is indeed possible that the presentation and representation of these three Greek physicians in the biographical dictionaries is in fact part of a general interest in associating medical knowledge with Islam in terms of both chronology and actual figures, and that this interest was out of necessity. Thus such biographies should not be regarded as signs of that the cultivation of science was being rejected or was under criticism. Rather, they should be read and analysed within the context of the search for the origin of medical knowledge, and the Islamic relation to these sources.

Sarah Stroumsa argues that "freethinkers" such as the theologian Ibn al-Rāwandi (d. in the $9^{\text {th }}$ century) and the philosopher Abu Bakr alRāzì (d. circa 925), responding to the "central importance of prophecy in Islam" rejected divine revelation and the theme of prophethood altogether. They argued that human intellect is the "source for all knowledge". Stroumsa argues that such radical views emerged as "a typically Islamic phenomenon". For her, this rejection is the main characteristic of the views of these two thinkers. Stroumsa also discusses the influence of these claims on later generations in Islam. ${ }^{100}$ We would therefore like to suggest that texts such as the biographies aimed to respond to such claims, through confirming the divine, revelatory and even prophetic source of medical knowledge, thus reassuring readers of the significance of prophethood. Turning the Greek doctors into part of the Islamic heritage and context would suit such intra-Islamic discussion.

A similar view was held by al-Bīrūnī (973-c. 1050). In his Risāla, he quotes passages from Galen's treatises, describing both Asclepius

99 Perho, The Prophet's Medicine, p. $53 \mathrm{ff}$ (see 78 for the quote). Further examination of this subject is necessary in order to illuminate the relation between the emergence of biographies such as those discussed above and the consolidation of the prophetic medicine genre.

100 Stroumsa, Freethinkers of Medieval Islam, pp. 13-21 and chapters 5-7. 
and Dionysius as having been turned by God into angels due to their knowledge: Asclepius in medicine, and Dionysius in wine-making. Such a reference seems unusual in an Islamic context. It might be that al-Bīrūnī included it in his book in order to eliminate the relationship between medicine and religion, as his view was that medical knowledge evolves from the human mind. ${ }^{101}$

Ibn Mutrān (d. 1191, Egypt), the court physician of Șalāh al-Dīn, also rejects the notion that medicine originated in prophecy. In his Bustān al-Atibb $\bar{a}$ ' he regards the view that the medical profession emerged through revelation and inspiration as a mistake (khat'). For him, this is an underestimation of the human minds that produced this knowledge. ${ }^{102}$

Other narratives also prevailed among Muslim scholars concerning the origins of medicine. These narratives situated medicine in varied places and periods, or associated the beginning of medicine with figures other than the Greek physicians. ${ }^{103}$ In addition, some medieval scholars had a different image of Galen and his medical knowledge, and one can find some harsh criticism against his philosophical and medical treatises. ${ }^{104}$

\section{Summary}

In this paper we have presented the biographies of three Greek physicians in Islamic biographical dictionaries. We suggested that the contents of these biographies could have been influenced by Greek

${ }^{101}$ Al-Bīrūnī, Risāla fi fihrist, pp. 25-26.

102 Ibn al-Muțān, Kitāb Bustān, p. 33.

103 A significant example is the Arab doctor, al-Hārith b. Kalada, who lived in the time of the Prophet Muhammad. See: Hawting, "The Development of the Biography", pp. 127-137. In her entry on Tibb in $E I^{2}$ (p. 451-460), Emilie Savage Smith argues that the story of Ibn Kalada is evidence of the great need of later Muslims to associate the use of medicine with the Prophet and his actions. Ibn Abì Ușaybi a for instance, mentions various possible sources for medicine, before discussing the possibility that Idris/Hermes was the first to cultivate medicine. Ibn Abī Ușaybie'a, 'Uȳ̄n al-Anbā', pp. 15-19.

104 There are three well-known critics of Galen: Alexander of Aphrodesia (who criticised Galen for his philosophical arguments, but praised him for his medical knowledge); al-Rāzī (d. 925), whose Kitāb al-Shukūk 'alā Jalīnūs awaits a study; and Maimonides. Chapter 25 of his Pirkei Moshe Bi-Refua is dedicated to demonstrating the contradictions in Galen's medical treatises. Maimonides argues that if Galen had these many contradictions in a subject which is supposedly his expertise, other fields that he wrote about are by far less reliable. Maimonides, Pirkei Moshe Bi-Refua. 
and/or Syriac sources that the authors of the dictionaries might have worked with. However, both the construction and the interpretation of these biographies represent an attempt to incorporate these Greek physicians into an Islamic framework. ${ }^{105}$

In our understanding, the construction of these biographies demonstrates how medicine was conceptualised by the authors; as a part of Islamic knowledge and of monotheistic history. It also illuminates some concealed assumptions about the way in which knowledge should be acquired and transmitted. The texts suggest that medicine should be thought about and practiced by individuals who are religiously and morally worthy; through the use of Islamic terminology in narrating the transmission of medical knowledge to humanity and to Muslims, an Islamic context has been created. This process of "Islamising" medicine enabled the incorporation of medicine into the Muslim world not only by practice, but also by nature.

It is still difficult to determine whether the association of moral behavior was part of the Islamic narrative of the transmission of medical knowledge in the $12^{\text {th }}$ and $13^{\text {th }}$ centuries; could it be that the social context of the authors inspired such a view of medicine? Or maybe it was a distinct characteristic of these particular three figures? In order to establish whether this was the case, it is necessary to study the five other physicians that appear in the "list of the eight", and the qualities that are ascribed to them. Such a study will also provide some insights into the place of the history of medicine within a general study of the transmission of knowledge.

\section{Bibliography}

Abbou Hershkovits, Keren, “Asclepius in Biographical Dictionaries", Studies in Early Medicine, 1 (2010), pp. 61-70.

Aeschylus, Prometheus Bound, J. Scully and C.J. Herington (transl.), New York and London, Oxford University Press, 1975.

${ }_{105}$ Another interpretation that needs to be studied thoroughly is that the presentation of these doctors in a monotheistic religious light and the idea that medicine is a divine gift evolve from the perception of Jesus as a miraculous healer. This view of Jesus is found in Christianity as well as in Islam. In the Dalä'il al-Nubuwwa (proofs of Muhammad's prophethood) literature, stories can be found that relate to Muhammad's similar characteristics. 
Aḥmad b. Hanbal Abū 'Abdallāh al-Shaybānī, Musnad al-Imām Aḥmad bin Hanbal, Egypt, Mu'assasat Qurțuba, n.d.

Allouche, Z.S., "Between the milk and the froth: Images of the Devil in the Muslim tradition (hadith)", unpublished doctoral thesis, London University, October 2006.

Alon, I., Socrates in Medieval Arabic Literature, Leiden, Brill, 1991.

Álvarez Millán, C., "Medical Anecdotes in Ibn Juljul's Biographical Dictionary", Suhayl, 2 (2004), pp. 141-158.

Al-Andalusī, Șāid, Kitāb Ṭabaqāt al-Umam, P. Louis Cheikho (ed.), Beirut, Imprimerie Catholique, 1912.

Balty-Guesdon, M.G., 'Les Ṭabaqāt al-Ațibbā'wa-l-Hukamā' d'Ibn Ğulğul: une condamnation du régime āmiride", in D. Aigle, J. Sublet et al. (eds.), Cahiers d'Onomastique Arabe 1988-1992, Paris, Ed. du CNRS, c. 1993, pp. 49-59.

Al-Bayhaqīi, Abū Bakr Ahmad b. al-Husayn, Dalā'il al-Nubuwwa wa-Ma'rifat Ahwwāl Șāhib al-Sharī’a, 'Abd al-Mu'țī Qal'ājī (ed.), Beirut, Dār al Kutub al'Ilmiyya, 1985.

Al-Bayhaqī, Zuhayr al-Dīn, Ta 'rīkh Hukamā'al-Islām, Mamdūḥ Ḥasan Muhammad (ed.), Cairo, Maktabat al-Thaqāfa al-Dīniyya, 1996.

Berkey, Jonathan P., "Tradition, Innovation and the Social Construction of Knowledge in the Medieval Islamic Near East", Past \& Present, 146 (1995), pp. 38-65.

Al-Bīrūnī, Risāla fì fihrist kutub Muhammad b. Zakarīyā al-Rāzī, P. Kraus (ed.), Paris, Mațba'at al-Qalam, 1936.

Bray, J., "Literary Approaches to Medieval and Early Modern Arabic Biography", Journal of the Royal Asiatic Society, 20 (2010), pp. 237-253.

Brentjes, Sonja, "Reflections on the Role of the Exact Sciences in Islamic Culture and Education between the Twelfth and the Fifteenth centuries", in Mohammed Abattouy (ed.), Etudes d'histoire des sciences Arabes, Casablanca, Fondation du roi Abdul-Aziz Al-Saoud, 2007, pp. 15-33.

Chamberlain, Michael, Knowledge and Social Practice in Medieval Damascus, 1190-1350, Cambridge, Cambridge University Press, 1994.

Charette, Francois, Mathematical Instrumentation in Fourteenth-century Egypt and Syria: The Illustrated Treatise of Najm Al-Dìn Al-Mīsrì, Leiden, Brill, 2003.

Cook, Michael, Commanding Right and Forbidding Wrong in Islamic Thought, Cambridge, Cambridge University Press, 2000.

Crisciani, Chiara, "History, Novelty, and Progress in Scholastic medicine", Osiris, 6 (1990), pp. 118-139.

Delbanco, A., The Death of Satan: How Americans Have Lost the Sense of Evil, New-York and Canada, Farrar Straus \& Giroux, 1995.

Dietrich, A., "Ibn al-Kiftị”, in P.J. Bearman et al., Encyclopcedia of Islam, 2nd edition, Leiden, E.J. Brill, 1960-2005.

Dietrich, A., "Ibn Djuldjul", in P.J. Bearman et al., Encyclopcedia of Islam, 2nd edition, Leiden, E.J. Brill, 1960-2005. 
Ebrahimnejad, H., "The Development of Galenic-Islamic Medicine, assimilation of Greek Sciences into Islam", Disquisitions on Past and Present, 13 (2005), pp. 127-140.

Edelstein, E. and Edelstein, L., Asclepius Collection and Interpretation of Testimonies, Baltimore and London, JHU Press, 1998 (rep.).

Fahd, T. and Daiber, H., "Ru'yā", in P.J. Bearman et al., Encyclopcedia of Islam, 2nd edition, Leiden, E.J. Brill, 1960-2005.

Fink, G., Who's Who in der Antiken Mythologie, H. Livnat (transl.), Israel, Maariv, 1998.

Friedmann, Y., Prophecy Continuous: Aspects of Ahmadī Religious Thought and Its Medieval Background, New Delhi, Oxford University Press, 2003 (first published in 1989).

Al-Ghazālī, Muḥammad, al-Munqidh min al-Ḍalāl, Beirut, Dā al-Kutub al-Lubnānī, 1985.

Gutas, D., Greek Wisdom Literature in Arabic Translation. A Study of the GraecoArabic Gnomologia, New Haven, American Oriental Society, 1975.

Halaf al-Ḥamārna, Sāmī, "Muslim Historiography as Related to the Health Professions", Sudhoffs Archiv, 50 (1944), pp. 229-247.

Hamilton, H.A.R, "Islamic Biographical Literature", in B. Lewis and P.M. Holt (eds.), Historians of the Middle East, London, New York, Toronto, Oxford University Press, 1962.

Hankinson, R.J., "The man and his work", in R.J. Hankinson (ed.), The Cambridge Companion to Galen, Cambridge, Cambridge University Press, 2008.

Hawting, G.R., "The Development of the Biography of al-Hārith ibn Kalada and the Relationship between Medicine and Islam", in C.E. Bosworth et al. (eds.), The Islamic World from Classical to Modern Times: Essays in Honor of Bernard Lewis, Princeton, Darwin Press, 1989.

Al-Haythamī, Nūr al-Dīn 'Alī, Majma' al-Zawā'id wa-Manba' al-Fawā 'id, CairoBeirut, Dār al-Riyān lil-Turāth-Dār al-Kitāb al-'Arabī, 1407/1986,

Ibn Abī Ușaybiea, Muwaffaq al-Dīn Abū l-'Abbās Aḥmād b. al-Qāsim b. Khalīfa b. Yūnus al-Khazrajī, Uyūn al-Anbā'fi Tabaqāt al-Ațibbā', G. Müller (ed.), Frankfurt, Institut für Geschichte der Arabisch-islamischen Wissenschaften, 1995 (rep.).

Ibn Ḥajar, Aḥmad b. 'Alī Abū l-Faḍl al-'Asqalānī al-Shāfiè̄, Fath al-Bārī: Sharh Sahīh al-Bukhārī, M.F. 'Abd al-Bāqī and M. al-Dīn al-Khațìb (eds.), Beirut, Dār al-Ma'rifa, 1379/1959.

Ibn Ḥajar, Aḥmad b. 'Alī Abū l-Faḍl al-'Asqalānī al-Shāfi ī, Tahdhīb al-Tahdhīb, Beirut, Dār al-Fikr, 1984.

Ibn Ḥibbān, Muḥammad b. Aḥmad Abū Ḥātim al-Tamīmī al-Bustī, Ṣaḥ̄h Ibn Hiibbān, S. al-Arnā'ūṭ (ed.), Beirut, Mu'assasat al-Risāla, 1993.

Ibn Juljul, Abū Dā'ūd Sulaymān b. Ḥassān al-Andalusī, Kitāb Ṭabaqāt al-Aṭibbā' 
wa-l-Hukamā', Fuad Sayed (ed.), Cairo, Impremirie de l'Institute Français d'Archéologie Oriental, 1955.

Ibn al-Muțrān, Muwaffaq al-Dīn Abū Nașr As'ad b. Ilyās, Kitāb Bustān al-ațibbāa' wa-rawdat al-alibba ', Tripoly, Jam 'iyat al-Da'wa al-Islamìya al-'Ālamiya, 1993.

Ibn al-Nadīm, Fihrist, Muṣtafā Muḥammad (ed.), Cairo, al-Maktaba al-Tijārīya al-Kubrā, 1929.

Ibn al-Qifṭị, Jamāl al-Dīn Abū l-Ḥasan 'Alī b. Yūsuf b. Ibrāhīm al-Shaybānī, Ikhbār al-'Ulamā' bi-Akhbār al-Hukamā', J. Lippert (ed.), Leipzig, Dieterichesche Verlagsbuchhandlung, 1903.

Jouanna, J., Hippocrate, M.B. De Bevoise (trans1.), Baltimore and London, Johns Hopkins University Press, 1999.

Kennedy, D., “Astronomy under the Mamluks”, Isis, 74 (1983), pp. 531-555.

Lapidus, I., A History of Islamic Societies, Cambridge and New York, Cambridge University Press, 2002, $2^{\text {nd }}$ ed.

Lecker, M., "Wādī 1-Kurā", in P.J. Bearman et al., Encyclopcedia of Islam, 2nd edition, Leiden, E.J. Brill, 1960-2005.

MacDonald, D.B., "Ilhām", in P.J. Bearman et al., Encyclopcedia of Islam, 2nd edition, Leiden, E.J. Brill, 1960-2005.

Maimonides, Pirkei Moshe Bi-Refua, Jerusalem, Mosad Harav Kook, 1959.

Al-Majlisī, Muḥammad Bāqir b. Muḥammad Taqī, Bị̣ār al-Anwār, Beirut, Dār Ihyē̄' al-Turāth al 'Arabīi, 1983.

Malti Douglas, F., "Controversy and Its Effects in the Biographical Tradition of Al-Khatīb Al-Baghdādī”, Studia Islamica, 46 (1977), pp. 115-131.

Manzalaoui, M., "The Pseudo-Aristotelian Kitāb Sirr al-Asrār: Facts and Problems", Oriens, 23-24 (1974), pp. 147-257.

Marín, Manuela, "Inqibạ̣̄ 'an al-Sulțān: 'Ulamā' and Political Power in al-Andalus", in Saber religioso y poder político en el Islam. Actas del Simposio Internacional (Granada, 15-18 octubre 1991), Madrid, AECI, 1994, pp. 127139.

Menn, S., "The Discourse on the Method and the Tradition of Intellectual Autobiography", in J. Miller and B. Inwood (eds.), Hellenistic and early modern philosophy, Cambridge, Cambridge University Press, 2003.

Monès, H., "The Role of Men of Religion in the History of Muslim Spain up to the End of the Caliphate", in Maribel Fierro and Julio Samsó (eds.), The Formation of Al-Andalus, part 2: Language, Religion, Culture and the Sciences, Hampshire, Ashgate 1998, pp. 51-85.

Al-Mubashshir b. Fātiq, Abū 1-Wafā', Mukhtār al-Hikam wa-Mahāsin al-Kilam, A. Badawī (ed.), Madrid, Maṭba'at al-Ma‘had al-Miṣrī li-1-Dirāsāt al-Islāmiyya, 1958.

Muslim b. al-Hajāj Abū 1-Husayn al-Qushayrī al-Naysābūrī, Șaḥ̄h Muslim, M.F. 'Abd al-Bāqī (ed.), Beirut, Dār Iḥyā' al-Turāth al-'Arabī, n.d. 
Al-Muttaqī al-Hindī, 'Alā' al-Dīn 'Alī b. Husām al-Dīn, Kanz al- 'Ummāl fì Sunan al-Aqwāl wa 'l-Af'āl, B. Hayānī and Ș. al-Siqā (eds.), Beirut, Mu'assasat al-Risāla, 1979.

Al-Nasā' '̄, Aḥmad b. Shu'ayb Abū 'Abd al-Raḥman, al-Sunan al-Kubrā, 'Abd alGhaffār Sulaymān al-Bandār and Sayd Kisrawī Ḥasan (eds.), Beirut, Dār alKutub al-'Ilmiyya, 1991.

Nutton, Vivian, "Galen in the Eyes of his Contemporaires", Bulletin of the History of Medicine, 58 (1984), pp. 315-324.

Pancaroğlu, Oya, "Socializing Medicine: Illustrations of the Kitāb al-Diryāq", Muqarnas, 18 (2001), pp. 155-172.

Perho, I., The Prophet's Medicine - A Creation of the Muslim Traditionalist Scholars, Helsinki, The Finnish Oriental Society, 1995, Studia Orientalia.

Petry, Carl, "Scholastic Stasis in Medieval Islam Reconsidered: Mamluk Patronage in Cairo", Poetics Today, 14, 2 (1993), pp. 323-348.

Pormann, Peter and Savage-Smith, Emilie, Medieval Islamic Medicine, Edinburgh, Edinburgh University Press, 2007.

Powers, D.S., Muhammad is not the Father of any of Your Men: the Making of the Last Prophet, Philadelphia, University of Pennsylvania Press, 2009.

Al-Qāḍì, W., "Biographical dictionaries as the scholars' alternative history of the Muslim community", in G. Endress (ed.), Organizing Knowledge: Encyclopaedic Activities in the Pre-Eighteenth Century Islamic World, Leiden, Brill, 2006, pp. 23-75.

Al-Qāḍī, W., "Biographical Dictionaries: Inner Structure and Cultural Significance", in G.N. Atiyeh (ed.), The Book in Islamic World: The Written Word and Communication in the Middle East, New York, State University of New York Press, 1995, pp. 93-122.

Al-Qurțubī, Abū 'Abdallāh Muḥammad b. Aḥmad b. Abī Bakr b. Faraj, Tafsīr al-Qurțubì, A. 'Abd al-'Alìm al-Bardūnī (ed.), Cairo, Dār al-Sha'b, $1372 / 1952$.

Reynolds, D.F., "Symbolic Narrative of the Self: Dreams in Medieval Arabic Autobiographies", in P.F. Kennedy (ed.), On fiction and "Adab" in Medieval Arabic Literature, Wiesbaden, Otto Harrassowitz Verlag, 2005.

Rosenthal, F., "Isḥāq b. Hunayn's Ta'rīh̆ al-Ațibbā',", Oriens, 7 (1954), pp. 55-80.

Rosenthal, F., A History of Muslim Historiography, Leiden, Brill, 1968.

Savage-Smith, E., "Tibb (a.)”, in P.J. Bearman et al., Encyclopcedia of Islam, 2nd edition, Leiden, E.J. Brill, 1960-2005.

Al-Shahrazūrī, Shams al-Dīn Muḥammad b. Mạ̣mūd, Nuzhat al-Arwāh wa-Rawdat al-Afrāh: Tawārīkh al-Hukamā', Alexandria, Dār al-Ma rifa al-Jam 'iyya, 1993.

Al-Sijistānī, Abū Sulaymān, Muntakhab Șiwān al-Hikma, D.M. Dunlop (ed.), The Hague, Paris, New York, Mouton, 1979.

Stroumsa, Sarah, Freethinkers of Medieval Islam: Ibn al-Rāwandī, Abū Bakr alRāzì, and Their Impact on Islamic Thought, Leiden, Boston, Köln, Brill, 1999. 
Al-Suyūtị, 'Abd al-Raḥmān b. Abī Bakr Jalāl al-Dīn, Kifāyat al-Ṭālib al-Labīb fì Khașā'iș al-Habìb, Beirut, Dār al-Kutub al-'Ilmiyya, 1985.

Al-Ṭabarī, Muhammad b. Jarīr Abū Ja far, Tafsìr al-Ṭabarì, Beirut, Dār al-Fikr, 1405/1984.

Temkin, O., Hippocrates in a World of Pagans and Christians, Baltimore and London, JHU Press 1991.

Al-Tirmidhī, Muhammad b. 'Īsā Abū 'Īsā al-Sulamī, al-Jāmi' al-Ṣah̄ịh Sunan alTirmidhī, A.M. Shākir et al. (eds.), Beirut, Dār Ihyyā' al-Turāth al-'Arabī, n.d.

Van Bladel, K., The Arabic Hermes from Pagan Sage to Prophet of Science, Oxford and New York, Oxford University Press, 2009.

Vernet, J., "Ibn Abī Ușaybi a", in P.J. Bearman et al., Encyclopcedia of Islam, 2nd edition, Leiden, E.J. Brill, 1960-2005.

Young, M.J.L., “Arabic Biographical Writing”, in M.J.L.Young, J.D. Lathman and R.B. Serjeant (eds.), Religion, Learning and Science in the Abbasid Period, Cambridge, Cambridge University Press, 1990, pp. 168-187.

Yūcesoy, H., "Translation as Self-Consciousness: Ancient Sciences, Antediluvian Wisdom, and the "Abbasid Translation Movement", Journal of World History, 20 (2009), pp. 523-557.

Zimmermann, F.W., “The Chronology of Ishāa Ibn Ḥunayn's 'Ta'rīkh al-Aṭibbā'”, Arabica, 21 (1974), pp. 324-330.

Recibido: 12/12/2010

Aceptado: 04/06/2012 